\title{
Exposure of FeCrAl Overlay Welds on Superheater Tubes: Influence of Local Environment on Degradation
}

\author{
M. A. Valiente Bermejo (i) $\cdot$ L. Magniez $\cdot$ A. Jonasson • \\ S. Selin · M. Frodigh • K. Hurtig • L-E. Stridh • L. Karlsson
}

Submitted: 6 December 2021 / in revised form: 15 December 2021/Accepted: 28 December 2021/Published online: 13 January 2022 (C) The Author(s) 2022

\begin{abstract}
Two experimental FeCrAl alloy overlay welds on tube shields were exposed in the superheater of a fullsize waste fired boiler for 6 months. The tube shields were in different tube lines and positions within the superheater chamber to investigate possible heterogeneities in the exposure environment. The visual inspection of the exposed tube shields and the corrosion-erosion rates calculated from the analysis of cross-sections showed that the mid-length roof location experienced the most aggressive environment. The compositional differences between the two experimental alloys were not found to be determinant in their performance under these specific exposure conditions. It was concluded that erosion had a decisive influence on the results. The identification of local differences within the superheater chamber is important when deciding on the material selection for the different areas and locations to be protected. The output of this study is therefore interesting for further design consideration of superheaters as well as for future planning of exposures.
\end{abstract}

M. A. Valiente Bermejo $(\varangle) \cdot$ K. Hurtig · L-E.Stridh ·

L. Karlsson

Department of Engineering Science, University West, 46186

Trollhättan, Sweden

e-mail: asun.valiente@hv.se

L. Magniez

École d'Ingénieurs de Limoges, Université de Limoges, 87280

Limoges, France

A. Jonasson

E.ON Värme Sverige AB, 60171 Norrköping, Sweden

S. Selin

Kanthal, 73427 Hallstahammar, Sweden

M. Frodigh

Sandvik Materials Technology, 81181 Sandviken, Sweden
Keywords Boiler - Superheater - Overlay welding · FeCrAl alloys

\section{Introduction}

Sustainability is a challenge for energy production companies, which aim for more efficient and more environmentally friendly combustion in waste incineration plants and in energy production. Regardless of conventional energies based on fossil fuels (coal, gas, oil) or renewable energies (biogas, biomass), there is a demand in power generation industries for increasingly efficient hightemperature materials with longer service life, high strength/weight ratio, and resistance to extreme environments.

$\mathrm{FeCrAl}$ alloys match these requirements, and their potential fields of application could be vast in many industries: in power generation industry for the fabrication of boilers, furnaces, radiant tubes, furnace fittings, but also in high-temperature process plants, concentrated solar power plants and in the nuclear industry.

$\mathrm{FeCrAl}$ alloys are ferritic iron-chromium-aluminium alloys for use at high-temperature corrosive environments. It is well known that corrosion and oxidation resistance of stainless steels relies on the formation of a protective oxide layer in contact with the media. The slower the growth of that protective oxide layer, the longer the service life of the component. In FeCrAl alloys, because of their high $\mathrm{Al}$ and $\mathrm{Cr}$ contents, the maximum continuous operating temperature (in air) is up to $1425{ }^{\circ} \mathrm{C}$ [1]. This high-temperature service coupled with their resistance to carburization, oxidation, and sulphidation environment makes $\mathrm{FeCrAl}$ alloys promising for the energy industry. 
$\mathrm{FeCrAl}$ alloys have been and are still under investigation regarding, for example, the influence of different alloying elements on their weldability [2, 3], and the $475^{\circ} \mathrm{C}$ embrittlement phenomenon [4-8]. Some authors investigated how to minimize imperfections in laser welding of FeCrAl alloys [9], and fundamental studies were conducted on their creep and tensile properties [10]. However, in the last years, in addition to the research conducted in the power generation industry, there has been a boost in the investigation of $\mathrm{FeCrAl}$ alloys as novel high-temperature coatings in the field of nuclear power generation [11-17]. FeCrAl alloys have been considered for reactor core internal applications and as claddings not only because of their superior oxidation and corrosion resistance in hightemperature but because of their radiation-induced cavity swelling resistance and the holding of their mechanical performance at and above typical light water reactor conditions. It means that the slow oxidation kinetics at high temperatures allow the cladding to remain intact longer, making accident mitigation more likely.

In power generation applications, tubes in the furnace walls and in the superheaters are normally made of low alloy carbon steel due to their low price, low risk of stress corrosion cracking, high heat transfer properties, and low thermal expansion. However, to extend their lifetime the current trend is to coat the low alloy steels with a more corrosion-resistant material. In the last years, some research works [11, 18, 19] evaluated the corrosion rate of several alloys under different environments (fired recycled wood and a fired mixture of sewage sludge with recycled wood). Results showed promising lower corrosion rate in FeCrAl alloy Fe21Cr5Al3Mo than in alloys such as AISI 310S (W Nr. 1.4845), EN 10028 16Mo3 (W Nr. 1.5415), and slightly lower than nickel-based alloy 625 (W Nr. 2.4856) [20].

There are several in-laboratory corrosion test methods for welds for specific corrosion types and in specific corrosive media; Pettersson et al. presented a useful compilation and review of them [21]. However, the hightemperature corrosive and erosive environment that is produced during waste combustion in the superheater is far from any standardized environment. The superheater is exposed to a flue gas at high temperature containing corrosive species such as chlorides, but at the same time, they are exposed to erosion because of solid particles carried by the flue gas. The time exposure in the standards is usually shorter than the boiler exposure cycle of 6 months and the specimen size used in this study is full-size, whilst in the standardized tests, it is in a short scale without the possibility to investigate the homogeneity of the real corrosive environment.

Our investigation aims at studying the corrosion-erosion resistance of overlay welds using two new experimental
FeCrAl alloys on a low-alloy steel tube substrate, which were exposed on-site in a boiler combusting household and industrial waste for an actual 6-month operational cycle. In addition to the corrosion-erosion resistance comparison between the alloys, this study will focus on the identification of possible heterogeneities in the environment in the secondary superheater of the boiler. Knowledge about the most aggressive locations in the superheater is crucial information for planning of test exposures aiming at having a consistent method to compare the performance of the overlay welds.

\section{Experimental}

\section{Materials and Weld Cladding}

Two experimental FeCrAl alloys were used in the clad preparation for this study, whose difference in terms of main elements is the silicon content (Table 1). The substrate used was EN 10028 16Mo3 (W Nr. 1.5415), which is a structural carbon steel with molybdenum content between 0.25 and $0.35 \%$ for service temperatures below $500{ }^{\circ} \mathrm{C}$. The substrate was clad in 2-meter tube form, $4 \mathrm{~mm}$ wall thickness and $38 \mathrm{~mm}$ outer diameter.

Circumferential mechanized GMAW was used to deposit one-layer claddings of one-meter length on the above-mentioned tubes (Fig. 1). The tube was water-cooled internally during the arcing time. The settings used in the overlay welding used for both alloys are shown in Table 2.

Two tubes were clad, one with each FeCrAl alloy. Once the tubes were clad, they were cut longitudinally into two halves, resulting in two tube shields for each alloy to be exposed in the boiler.

\section{Exposure}

The exposure took place in the waste fired plant designated as P14 at Händelö (Sweden). It consists of a boiler, steam turbine, flue gas cleaning, and fuel preparation with capacity for combustion of 200000 Tons/Year and a thermal capacity of $75 \mathrm{MW}$ (Fig. 2).

The boiler is a circulating fluidized bed (CFB) boiler, and it produces steam, primarily used to produce electricity, industrial process steam, and district heating. The boiler is designed for fuel flexibility, using a fuel mix of

Table 1 Nominal composition of the FeCrAl wires (wt. \%)

\begin{tabular}{llllcl}
\hline FeCrAl alloy & $\mathrm{Cr}$ & $\mathrm{Al}$ & $\mathrm{Si}$ & $\mathrm{Mn}, \mathrm{C}, \mathrm{Ni}, \mathrm{Nb}, \mathrm{N}$ & $\mathrm{Fe}$ \\
\hline $\mathrm{A}$ & 12.5 & 3.7 & 1.3 & $<1.5 \%$ & 81 \\
$\mathrm{~B}$ & 10 & 4 & 0.3 & $<1.5 \%$ & 84 \\
\hline
\end{tabular}




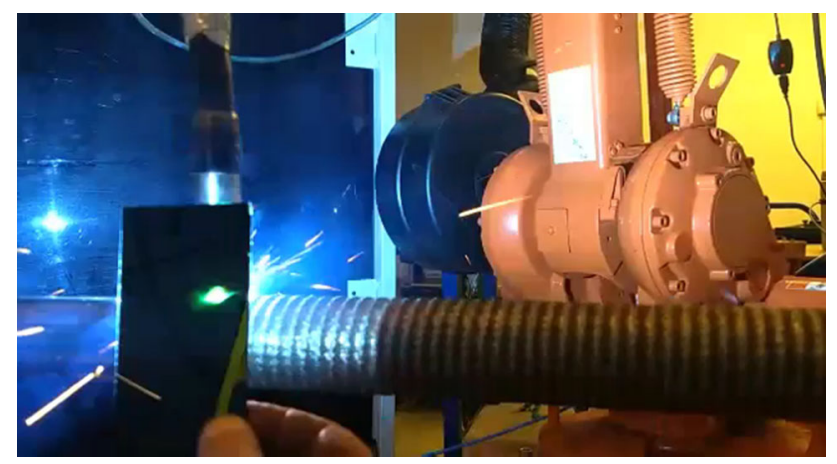

Fig. 1 Circumferential mechanized GMAW used to deposit onelayer cladding of FeCrAl alloy on the EN 10028 16Mo3 (W Nr. 1.5415) substrate tubes

Table 2 Overlay welding settings

\begin{tabular}{lccccc}
\hline $\begin{array}{l}\text { Current } \\
(\mathrm{A})\end{array}$ & $\begin{array}{c}\text { Voltage } \\
(\mathrm{V})\end{array}$ & $\begin{array}{c}\text { Welding } \\
\text { speed }(\mathrm{mm} / \mathrm{s})\end{array}$ & $\begin{array}{c}\text { Stick-out } \\
(\mathrm{mm})\end{array}$ & $\begin{array}{c}\text { Shielding } \\
\text { gas }\end{array}$ & $\begin{array}{c}\text { Interpass } \\
\mathrm{T}\left({ }^{\circ} \mathrm{C}\right)\end{array}$ \\
\hline $\begin{array}{c}145+/ \\
-5\end{array}$ & $21+/-1$ & 5 & $12-14$ & Argon & $\sim 100$ \\
\hline
\end{tabular}

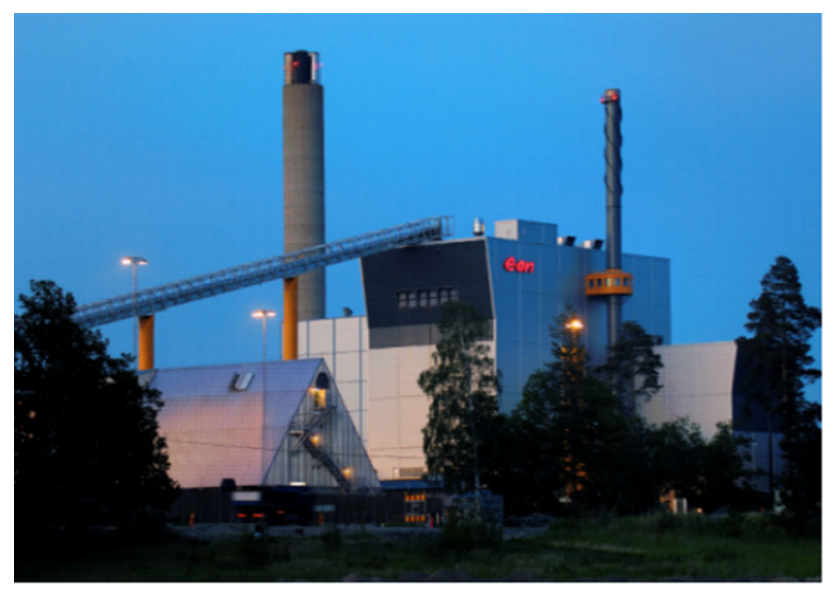

Fig. 2 The waste fired plant P14 at Händelö (Sweden) where the exposure took place

30-50\% combined household waste, $50-70 \%$ classified industrial waste, and up to $20 \%$ of sewage sludge.

The main parts in the boiler system are a water-cooled furnace with two integrated water-cooled cyclones and loop seals, containing the final superheaters, and an external ash-classifier (Fig. 3). The cyclones are followed by a single-pass radiation cavity (empty pass) and a convection pass with superheater banks, boiler banks, and economizer banks.
The exposure took place in the secondary superheater (Fig. 3). It comprises different levels, and the specific level, designated as number 6 , is found close to the bottom of the bank, right above the evaporator bank. There were 100 tubes in this level: 50 tubes located on the floor and 50 tubes located in the roof. The tube shields clad with alloy "A" were placed on tube number 6 in the roof and the same tube number on the floor, whilst the tube shields clad with alloy "B" were both placed in the roof, on tubes 9 and 12 (Fig. 4). There were 2 steam soot blowing systems, each one located at each side of the level 6 chamber and covering half of the volume of the chamber. The steam soot blowers are operational for 6 minutes every 24 hours.

The P14 plant has two maintenance stops during the year. During the stop in the autumn, the clad tube shields were installed in the location described previously. Then the plant was back to operation with the tube shields exposed during the next 184 days, in which the boiler was in continuous operation for 163 days.

Table 3 shows the average values of the operational data registered in the secondary superheater during the exposure time. The location where $\mathrm{HCl}, \mathrm{SO}_{2}, \mathrm{H}_{2} \mathrm{O}$ and $\mathrm{O}_{2}$ were measured is indicated in Fig. 3. In the specific case of $\mathrm{O}_{2}$, measurements were taken on the left and right sides in the flue gas channel.

The tube shields were removed from the superheater during the maintenance stop scheduled for the following spring.

Methodology: Handling the Exposed Samples and Preparation for Analysis

During a maintenance stop in the superheater, the cleaning operations are the first to be conducted. To avoid the corrosion products and the remaining claddings in the tube shields to be affected by those operations, the tube shields were protected (Fig. 5) before being removed.

Once the tube shields were taken out from the superheater, they were visually inspected. After visual inspection, two coupons were extracted from each tube shield to investigate the cross-section of the overlay. This was done by cutting at two different locations; one coupon was extracted at $25 \mathrm{~mm}$ of the end of the clad (labelled as " 1 ") and the second one in the center of the clad length, at $1 \mathrm{~m}$ distance from the edge (labelled as "2"), see Fig. 6.

Cutting was conducted at $750 \mathrm{rpm}$ (Buehler Abrasimet 2) with Struers $50 \mathrm{~A} 20$ cutting wheel and feed speed between 0.040 and $0.050 \mathrm{~mm} / \mathrm{s}$. The specimens were mounted in epoxy and ground and polished according to conventional metallographic preparation procedures. 


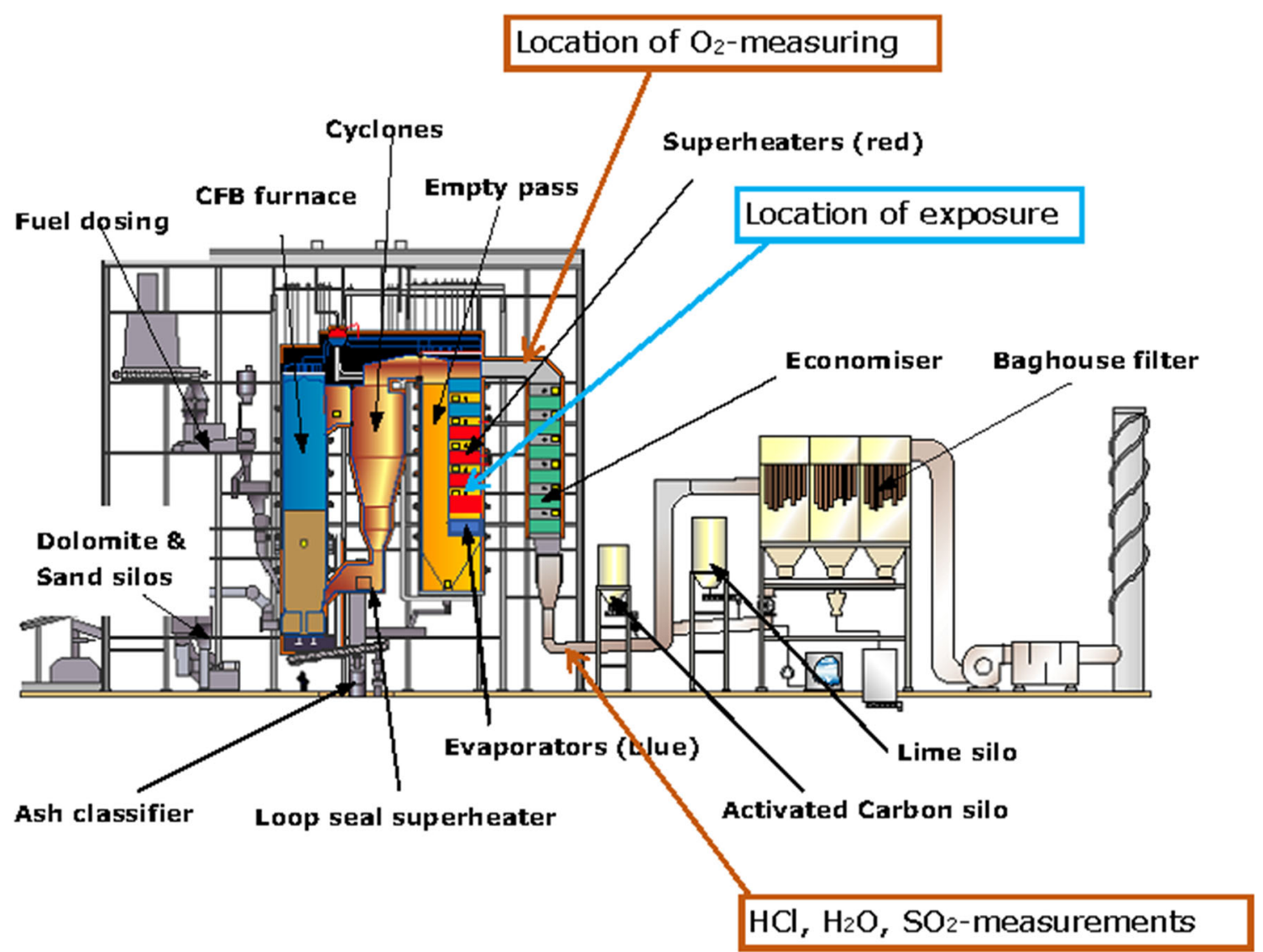

Fig. 3 Synoptic of the boiler system, showing the secondary superheater location where the claddings were exposed. The locations where the measurements of $\mathrm{O}_{2}, \mathrm{HCl}, \mathrm{SO}_{2}$ and $\mathrm{H}_{2} \mathrm{O}$ were taken are also indicated

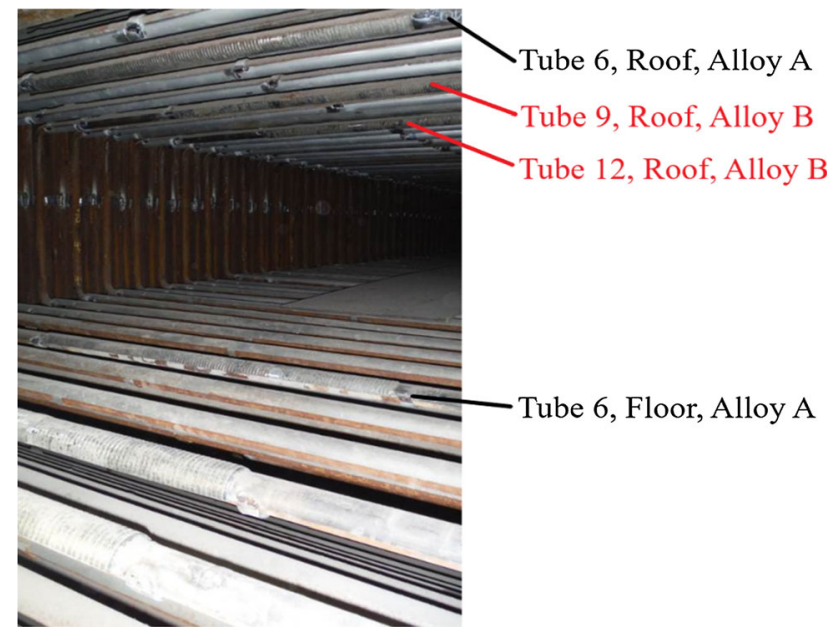

Fig. 4 Level 6 in the secondary superheater showing the tubes located on the floor and in the roof and indicating the position of the claddings exposed. Flue gas flow passes through the chamber vertically from bottom to top

To investigate the cross-sections and evaluate the metal loss rate, a light optical microscope (Zeiss Axio Imager) and image analysis software (Image Pro-Premier) were used. The length and area of the cladding were measured before and after the exposure for each alloy and location (Fig. 7).

\section{Results}

Results from visual inspection of the exposed specimens and the examination of the cross-sections are presented below to show the corrosion-erosion resistance of the overlay claddings in connection to the location of the tube shields.

\section{Visual Inspection}

Figure 8 shows the tube shields just after being extracted from the boiler. As described previously, except for tube 6 on the floor clad with alloy A, the other three tube shields were exposed in the roof of the chamber. The visual inspection revealed that the tube shield cladding with alloy $\mathrm{A}$ and exposed on the floor showed thinner corrosion deposits than the other three tube shields exposed in the roof. The tube shield in the worst condition was exposed in 
Table 3 Operational and environmental data. Average values during service

\begin{tabular}{lcccccc}
\hline $\begin{array}{l}\text { Flue gas } \\
\begin{array}{l}\text { Temperature } \\
\left({ }^{\circ} \mathrm{C}\right)\end{array}\end{array}$ & $\begin{array}{c}\mathrm{HCl} \text { before flue gas } \\
\text { cleaning }\left(\mathrm{mg} / \mathrm{Nm}^{3}\right)^{*}\end{array}$ & $\begin{array}{c}\mathrm{SO}_{2} \text { before flue gas } \\
\text { cleaning }(\mathrm{mg} / \\
\left.\mathrm{Nm}^{3}\right)^{*}\end{array}$ & $\begin{array}{c}\mathrm{H}_{2} \mathrm{O} \text { before flue } \\
\text { gas cleaning (vol. } \\
\%)\end{array}$ & $\begin{array}{c}\mathrm{O}_{2} \text { in flue gas } \\
\text { left side (vol. } \\
\%)\end{array}$ & $\begin{array}{c}\mathrm{O}_{2} \text { in flue gas } \\
\text { right side }(\text { vol. } \\
\%)\end{array}$ & $\begin{array}{c}\text { Steam Temperature after } \\
\text { secondary superheater } \\
\left({ }^{\circ} \mathrm{C}\right)\end{array}$ \\
\hline 593 & 463,06 & 20,41 & 14,24 & 6,43 & 5,72 & 416 \\
\hline
\end{tabular}

*Note (mg/Nm3) refers to milligrams per cubic meter. The " $\mathrm{N}$ " refers to normalized temperature and pressure conditions $\left(0{ }^{\circ} \mathrm{C}\right.$ and 1 atm).

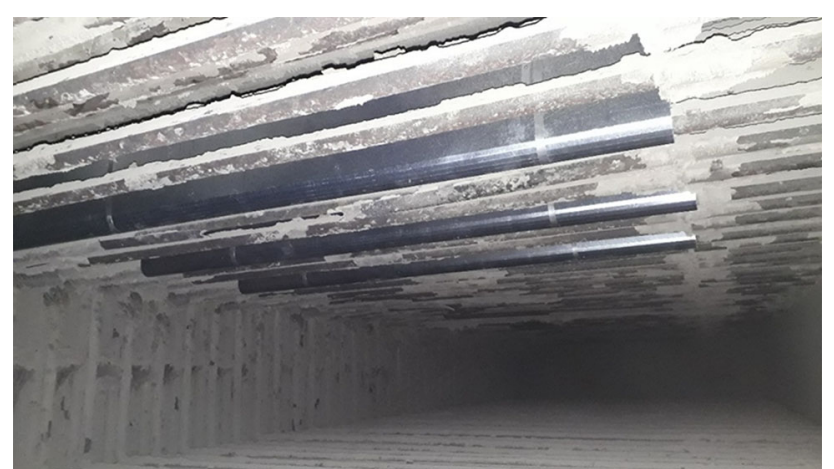

Fig. 5 Level 6 in the secondary superheater showing the exposed tube shields protected in the roof, to avoid affecting them with the sand blasting and cleaning operations

the roof on tube 12 and clad with alloy B, which was completely broken in the middle of the length.

When comparing claddings of alloy A, Fig. 9 reveals in more detail the difference observed in the thickness of the corrosion deposits based on the roof/floor location. Thick corrosion products and signs of corrosion-erosion progressing all through the cladding and the substrate were observed in the tube shield exposed in the roof, whilst thinner corrosion products and material integrity are observed for the tube shield exposed on the floor.

When looking at the claddings of alloy $\mathrm{B}$, all of them in the roof, Fig. 10 shows the difference found in the corrosion products formed. In all cases, the outer corrosion product is thick, breakable and easily removable. In tube shield on tube 9 , there was a very thin $(1 \mathrm{~mm})$ layer of corrosion products on the inner side of the tube shield. However, in the tube shield on tube 12, corrosion progressed massively through the inner side of the tube shield, most probably because of corrosion progressing through the EN 10028 16Mo3 substrate.

\section{Corrosion-Erosion Rate}

The image analysis of the cross-sections before and after the exposure resulted in the calculation of the cladding cross-section area that was lost per length unit $\left(\mathrm{mm}^{2} / \mathrm{mm}\right)$. Considering that the exposure lasted for 6 months, the corrosion-erosion rate (loss of cladding thickness in $\mathrm{mm} /$ year) was therefore calculated and is plotted in Fig. 11 for each cladding alloy and exposure location.

\section{Discussion}

The results will be discussed in connection to three aspects: the estimated lifetime, the local variations in the exposure environment and the chemical composition of the alloys.

Considering that the average overlay clad thickness asdeposited was $3 \mathrm{~mm}$, the lifetime of the cladding was estimated (and shown in Fig. 12) based on the calculated corrosion-erosion rate.

As depicted in Figs. 11 and 12, the claddings exposed in the roof experienced higher corrosion-erosion rates and therefore a shorter estimated lifetime is expected than for the claddings exposed on the floor. The results also confirm that claddings in location 2, at mid-length of the tube shield, were more severely corroded than in location 1 close to the end of the cladding length. In fact, the substrate and the clad material for the samples exposed in the roof were completely consumed in the mid-length location during exposure (A-6R-2, B-9R-2 and B-12R-2).

To compare the corrosion-erosion resistance of the different alloys, it has to be considered that alloy B was not exposed on floor positions and that all the roof exposures in the mid-length location (2) were completely consumed after the 6 months exposure. Therefore, only the performance of alloys $A$ and $B$ in the roof in location 1 will be used for comparison (A-6R-1, B-9R-1 and B-12R-1). The percentage of cross-section area loss during the exposure was found to be $44 \%$ for alloy A in tube 6 and for alloy B was 55 and $41 \%$, respectively, in tubes 9 and 12 . Corrosion-erosion rates (Fig. 11) and estimated lifetime (Fig. 12) for both alloys in location 1 were consequently very similar.

From the results, the environment in the superheater is not homogeneous. The tube shields exposed in the roof of the chamber experienced a faster degradation than the tube shields exposed on the floor for both alloys. The central top area in the chamber, where the mid-length of the tube shields is located, showed the highest corrosion-erosion rate. That specific location on the three tube shields exposed in the roof revealed that not only the clad material 


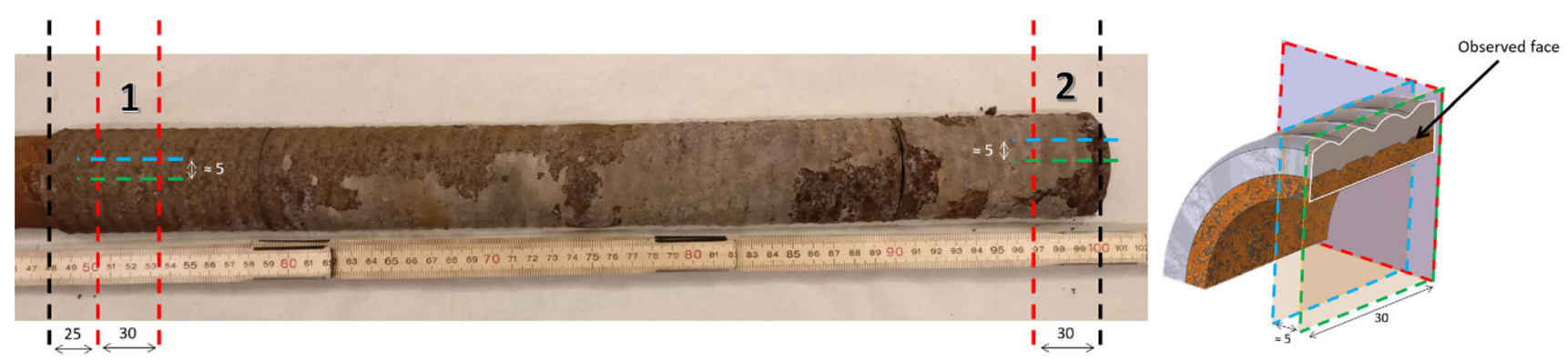

Fig. 6 Location of the 2 coupons extracted per tube shield. One at $25 \mathrm{~mm}$ of the end of the cladding (1) and the other in the center of the cladding length (2). On the right, the cross-section of the overlay weld is sketched

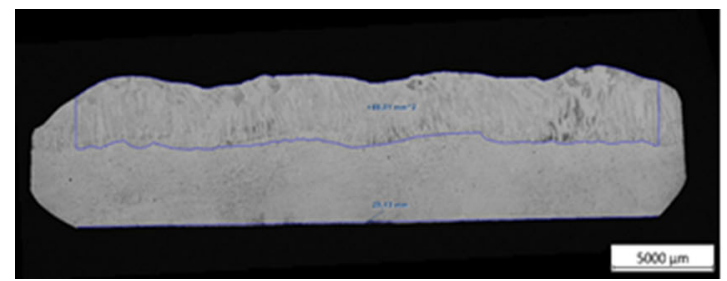

Fig. 7 Example of overlay cross-sections investigated. Left: Alloy B cladding before exposure. Right: Alloy B cladding exposed on tube 9 (roof) and position 1 (at $25 \mathrm{~mm}$ from the end of the clad, see Fig. 6). The clad area is underlined in blue at the top of the images, whilst the

but also the substrate was consumed by the corrosionerosion action. The heterogeneity in the exposure environment can be explained mainly by the design and configuration of the CFB boiler. In this type of boiler, the flue gas stream passes through the superheater chambers circulating vertically from the bottom to the top (Fig. 4) at high speed. Just before the superheater channel, the flue gas speed is approximately $8 \mathrm{~m} / \mathrm{s}$, and because of the area reduction when crossing the chamber, the speed is expected to increase in the chamber. Therefore, the tube shields exposed in the roof of the chamber are the ones experiencing the direct impact of any solid particle carried by the flue gas. Computational fluid dynamics (CFD) has been used to model the fluidized bed combustion systems, and different turbulence models have been applied to simulate the flue gas flow in the boilers [22]. Dixon et al. [23] used CFD to support the experimental erosion observed in the convection bank tubes of the superheater in a "Bagasse" boiler type. The gas flow dynamics showed that in some orientations, the ash particle streams were concentrated and impacted on tubes at specific locations, whilst in other areas the density of particles and the impact angle were lower. Similar considerations may also be applied to this CBF boiler and might support the observations in this work. Another element that could have influenced on the heterogeneity of the environment is the soot blowing. Probably it helped in removing the corrosion product preferentially in the mid-length of the tube shields, and consequently leaving a fresh metal surface exposed, which

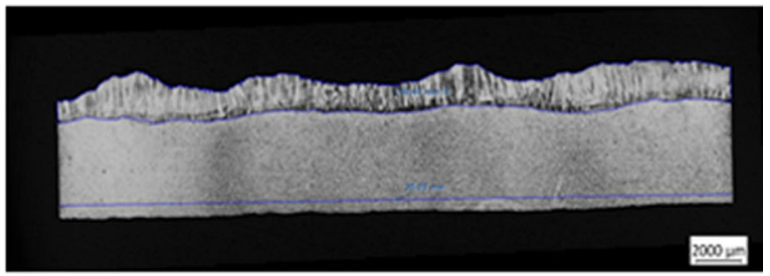

EN $1002816 \mathrm{Mo} 3$ substrate is at the bottom of the images. The width of the cross-sections is shown as a blue line close to the bottom of the substrate. Images taken at the same magnification

in turn would decrease the self-protection of the $\mathrm{FeCrAl}$ alloys against corrosion locally. However, this influence would be expected in both room and floor tube shields.

It is well known that the addition of silicon to stainless steels enhances their corrosion resistance due to the formation of silicon-based oxides at high temperature [24-26]. It is recognized that the synergy between the addition of aluminium and silicon increases, even more, the corrosion resistance of $\mathrm{Fe}-\mathrm{Cr}$ alloys, creating a barrier for chromium to diffuse to the media and for chloride in the media to diffuse into the matrix [27]. Initially, it would have been expected a different performance between alloy A with $1.3 \%$ silicon content and alloy B with $0.3 \%$ silicon (Table 1). The fact that both alloys performed similarly in this study can indicate that in this level 6 chamber in the superheater, the erosive mechanism has been crucial. Level 6 is located right above the evaporator bank, close to where the flue gas enters just after having passed the cyclone (Fig. 3). Therefore, this is a location where remaining solid particles that were not removed by the cyclone can be expected and consequently erosion is probably significant as referred before [23].

As the two alloys in this study are experimental, it is not possible to find published data on their performance in waste fired boilers. However, a previous study [28] was conducted in the superheater of P14 boiler in Händelö using tube shield claddings of 253MA, Hastelloy G-30, Haynes HR-160, 316L, 304L and commercial FeCrAl alloys (Kanthal APMT, Kanthal APM and Kanthal A-1), 
Fig. 8 Picture of the tube shields just after removal from the boiler. Claddings of alloy B were in the roof, and claddings of alloy A were exposed in both roof and floor locations

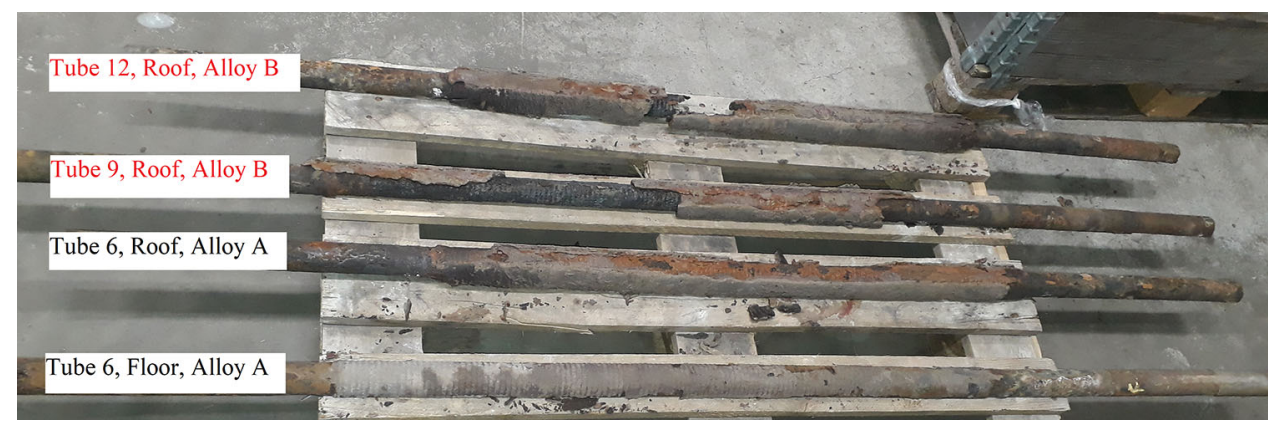

Fig. 9 Images of alloy A claddings in the mid-length of tube shield on tube 6 (location 2). Left: tube exposed on the floor. Right: tube exposed in the roof
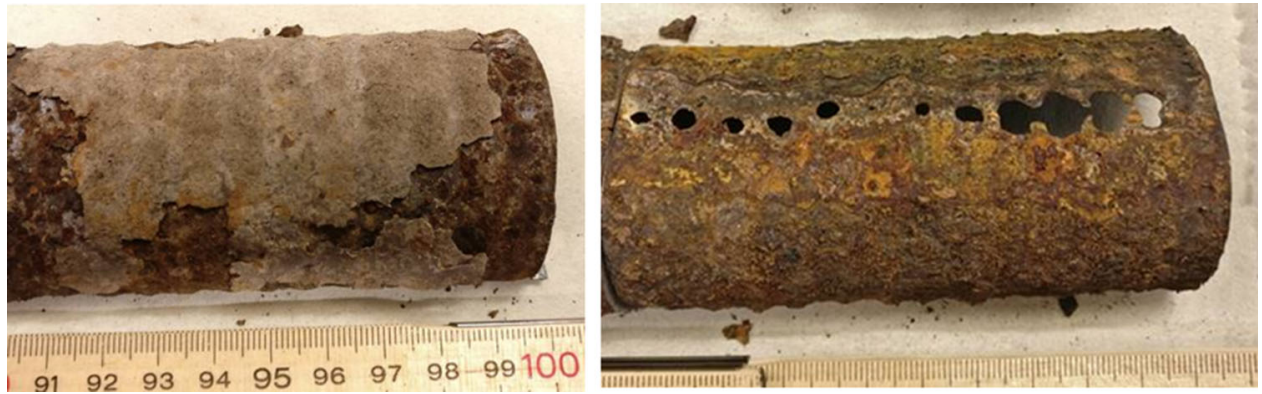

Fig. 10 Images of alloy B claddings of the tube shields exposed in the roof location. Left: tube shield on tube 9 . Right: tube shield on tube 12
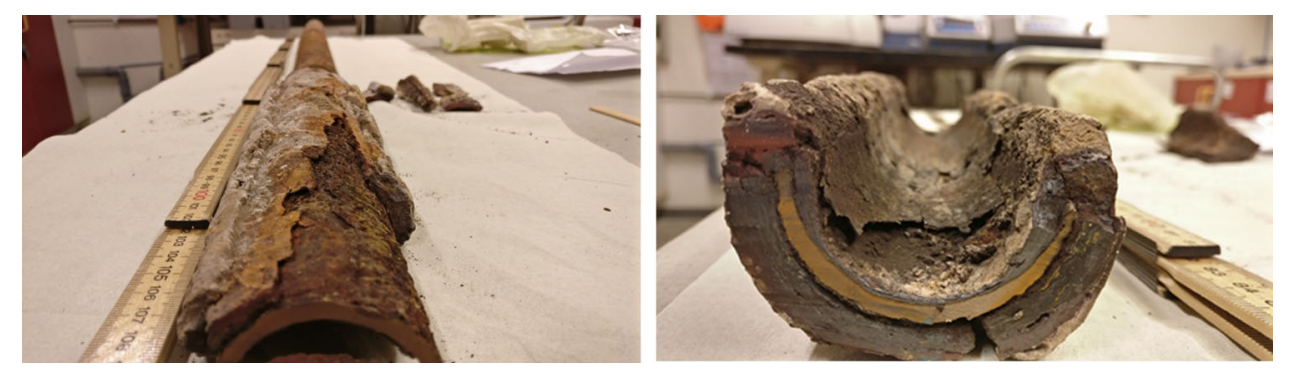

Fig. 11 Corrosion-erosion rate (loss of cladding thickness in $\mathrm{mm} /$ year) for each alloy (A, B), tube $(6,9$ or 12), location (F: floor and R: roof) and position along the tube shield (1: side near walls, 2: center of the tube) investigated

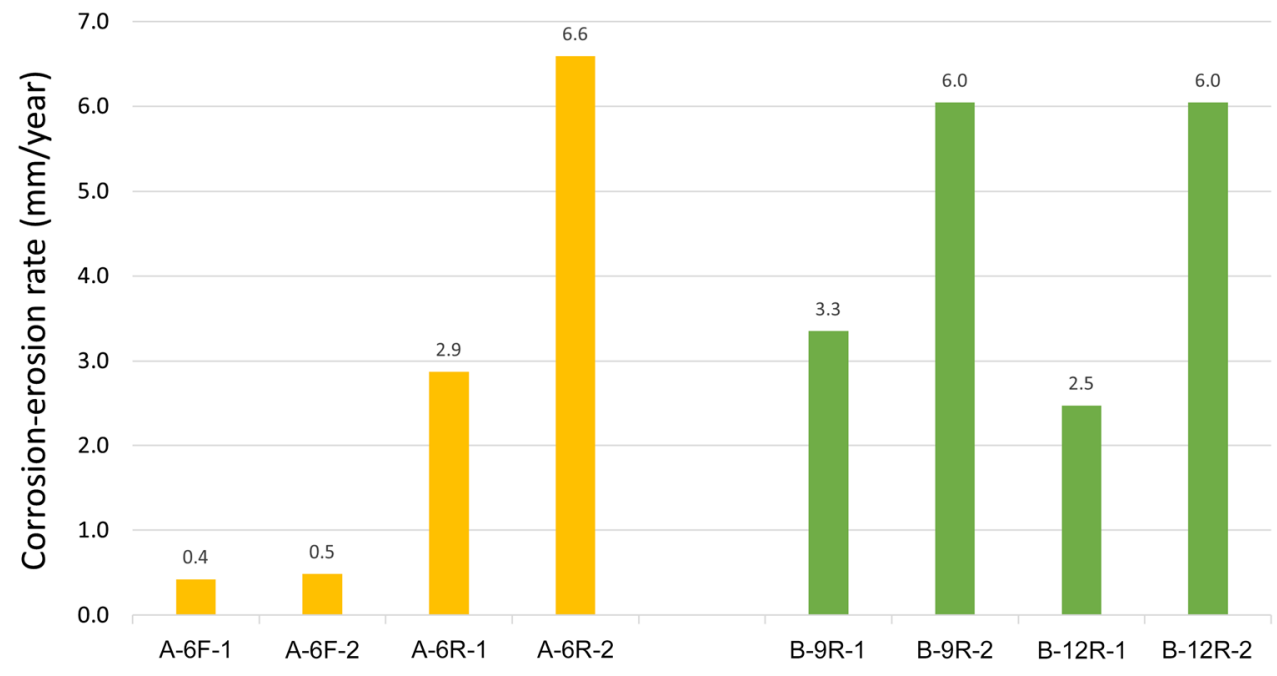

for 321 days and 492 days. The results showed less metal loss rate for the FeCrAl alloys (average of $0.6 \mathrm{~mm} / \mathrm{year}$ ) than for the rest of materials, for example $1 \mathrm{~mm} /$ year for
$253 \mathrm{MA}, 1.7 \mathrm{~mm} /$ year for 316L or $3.3 \mathrm{~mm} / \mathrm{year}$ for Haynes HR-160. When comparing the performance of the FeCrAl alloys in that study with the loss of cladding thickness for 
Fig. 12 Estimated lifetime (years) for each alloy (A, B), tube $(6,9$ or 12), location (F: floor and R: roof) and position along the tube shield (1: side near walls, 2 : center of the tube) investigated

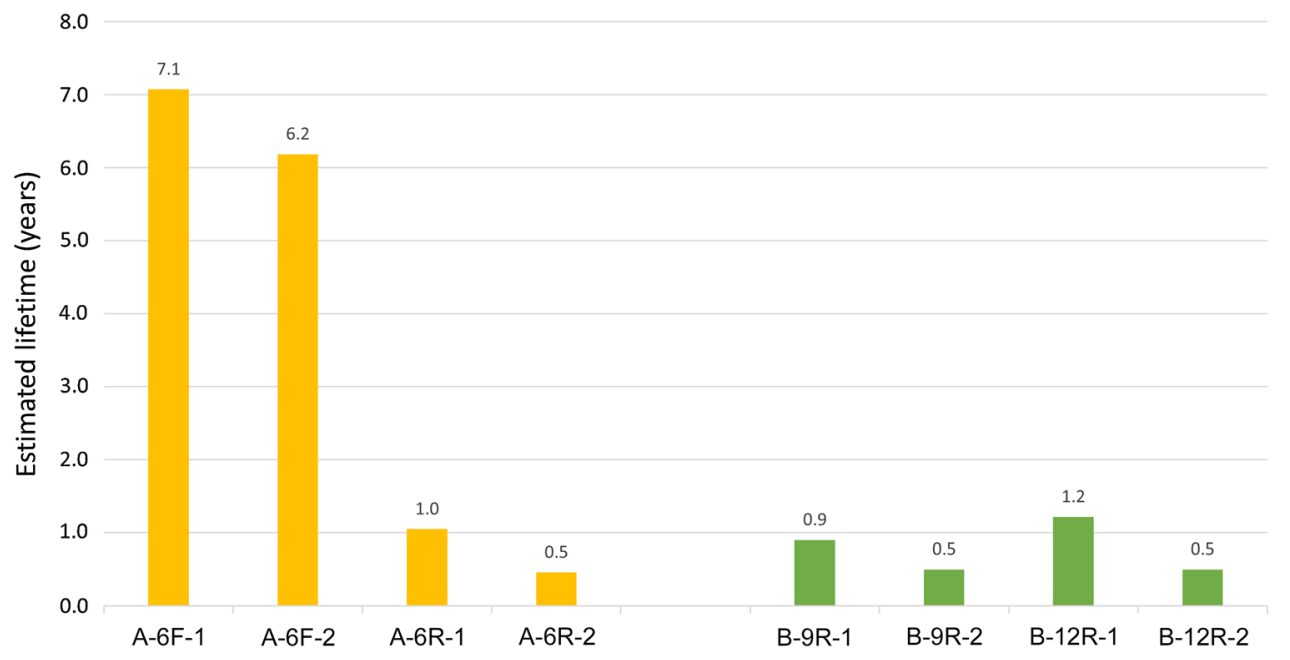

alloy A located on the floor $0.4-0.5 \mathrm{~mm} /$ year (Fig. 11), the performance of alloy A is promising in comparison with all the alloys tested in that former study.

In any case, to compare the corrosion-erosion resistance of the experimental $\mathrm{FeCrAl}$ alloys, it is necessary to conduct further exposures ensuring that all alloys will be exposed in both critical and less-critical areas in the superheater. Additional factors need to be investigated and compared in future exposures, for example, the operational and environmental conditions in the superheater, the comparison of these $\mathrm{FeCrAl}$ alloys with other alloys currently used for this type of application in the market, or the influence of the flue gas composition on the performance of the alloys, by using only recycled wood as fuel.

\section{Conclusions}

Two experimental FeCrAl alloys in the form of overlay welds on tube shields were exposed in the superheater of a full-size waste fired boiler for 6 months. The tube shields were in different tube lines and positions within the superheater chamber.

On the one hand, important local variations in the environment have been found, the most aggressive environment is in the middle-length of the tube shields in the roof. On the other hand, both $\mathrm{FeCrAl}$ alloys investigated showed very similar behavior in the samples located in the roof. Considering that one of them was enriched in silicon to improve its corrosion resistance, this makes it likely that the erosion mechanism was more significant than the corrosion mechanism in this specific exposure located at the lowest part of the superheater bank of the CBF boiler. The performance of alloy A when exposed on the floor tubes seems promising when comparing it to the metal loss rate of other commercial $\mathrm{FeCrAl}$ alloys and high-temperature corrosion-resistant alloys reported in the literature.

Further investigations with larger number of samples in the exposures are necessary to rank the corrosion-erosion resistance of experimental $\mathrm{FeCrAl}$ alloys and to compare them with reference alloys currently used in the superheaters. To conduct that comparison, it is necessary to ensure that each alloy to be studied is exposed in both roof and floor locations.

The use of computational fluid dynamics (CFD) could be an important asset to be used in connection to the exposures, to support and confirm the experimental observations and the corrosive-erosive conditions.

Wrong conclusions could be drawn when comparing the performance of the overlay-welded alloys if the location of the specimens is not considered and consequently the differences in the severity of the environment are neglected.

Acknowledgments This research was funded by KK-stiftelsen (Stiftelsen för kunskaps-och kompetensutveckling), grant number 20310117, dnr 20170198.

Funding Open Access funding provided by University West.

Open Access This article is licensed under a Creative Commons Attribution 4.0 International License, which permits use, sharing, adaptation, distribution and reproduction in any medium or format, as long as you give appropriate credit to the original author(s) and the source, provide a link to the Creative Commons licence, and indicate if changes were made. The images or other third party material in this article are included in the article's Creative Commons licence, unless indicated otherwise in a credit line to the material. If material is not included in the article's Creative Commons licence and your intended use is not permitted by statutory regulation or exceeds the permitted use, you will need to obtain permission directly from the copyright holder. To view a copy of this licence, visit http://creativecommons. org/licenses/by/4.0/. 


\section{References}

1. SMT Technical datasheets for Kanthal $\mathrm{APM}^{\mathrm{TM}}$ and Kanthal APMT $^{\mathrm{TM}}$ alloys

2. J.N. DuPont, J.R. Regina, K. Adams (2007) Improving the weldability of FeCrAl weld overlay coatings. Fossil Energy Materials Conference, ORNL, 131-137 (2007)

3. J.R. Regina, J.N. DuPont, A.R. Marder, The effect of chromium on the weldability and microstructure of $\mathrm{Fe}-\mathrm{Cr}-\mathrm{Al}$ weld cladding. Weld. J. 86, 170s-178s (2007)

4. W. Li, S. Lu, Q. Hu, H. Mao, B. Johansson, L. Vitos, The effect of $\mathrm{Al}$ on the $475{ }^{\circ} \mathrm{C}$ embrittlement of $\mathrm{Fe}-\mathrm{Cr}$ alloys. Comput. Mater. Sci. 74, 101-106 (2013)

5. S. Kobayashi, T. Takasugi, Mapping of $475{ }^{\circ} \mathrm{C}$ embrittlement in ferritic Fe-Cr-Al alloys. Scripta Materialia. 63, 1104-1107 (2010)

6. C. Capdevila, M.K. Miller, G. Pimentel, J. Chao, Scripta Influence of recrystallization on phase separation kinetics of oxide dispersion strengthened $\mathrm{Fe}-\mathrm{Cr}-\mathrm{Al}$ alloy. Scripta Materialia. 66(5), 254-257 (2012)

7. C. Capdevila, M.K. Miller, K.F. Russell, J. Chao, J.L. GonzálezCarrasco, Phase separation in PM $2000^{\mathrm{TM}}$ Fe-base ODS alloy: experimental study at the atomic level. Mater. Sci. Eng. A. 490, 277-288 (2008)

8. Z.G. Zhang, F. Gesmundo, P.Y. Hou, Y. Niu, Criteria for the formation of protective $\mathrm{Al}_{2} \mathrm{O}_{3}$ scales on $\mathrm{Fe}-\mathrm{Al}$ and $\mathrm{Fe}-\mathrm{Cr}-\mathrm{Al}$ alloys. Corrosion-erosion Sci. 48, 741-765 (2006)

9. K.G. Field, M.N. Gussev, Y. Yamamoto, L.L. Snead, Deformation behavior of laser welds in high-temperature oxidation resistant $\mathrm{Fe}-\mathrm{Cr}-\mathrm{Al}$ alloys for fuel cladding applications. J. Nucl. Mater. 454(1-3), 352-358 (2014)

10. H. El Kadiri, Y. Bienvenu, K. Solanki, M.F. Horstemeyer, P.T. Wang, Creep and tensile behaviors of $\mathrm{Fe}-\mathrm{Cr}-\mathrm{Al}$ foils and laser microwelds at high-temperature. Mater. Sci. Eng.: A. 421(1-2), 168-181 (2006)

11. K.G. Field, M.N. Gussev, X. Hu, Y. Yamamoto Preliminary results on $\mathrm{FeCrAl}$ alloys in the as-received and welded state designed to have enhanced weldability and radiation tolerance. Oak Ridge National Laboratory, Report TM-2015/579 (2015)

12. K.G. Field, X. Hu, K.C. Littrell, Y. Yamamoto, L.L. Snead, Radiation tolerance of neutron-irradiated model $\mathrm{Fe}-\mathrm{Cr}-\mathrm{Al}$ alloys. J. Nucl. Mater. 465, 746-755 (2015)

13. K.G. Field, S.A. Briggs, P. Edmondson, X. Hu, K.C. Littrell, R. Howard, C.M. Parish, Y. Yamamoto Evaluation of the effect of composition on radiation hardening and embrittlement in model FeCrAl alloys. Oak Ridge National Laboratory, Report TM-2015/ $518,(2015)$

14. M.N. Gussev, K.G. Field, Y. Yamamoto The analysis of the general performance and mechanical behavior of unirradiated FeCrAl alloys before and after welding. Oak Ridge National Laboratory, Report TM-2016/201, (2016)
15. R. Sweet, N. George, K. Terrani, B. Wirth BISON fuel performance analysis of $\mathrm{FeCrAl}$ cladding with updated properties. Oak Ridge National Laboratory, Report TM-2016/475, (2016)

16. X. Wu, T. Kozlowski, J.D. Hales, Neutronics and fuel performance evaluation of accident tolerant $\mathrm{FeCrAl}$ cladding under normal operation conditions. Ann. Nucl. Energy. 85, 763-775 (2015)

17. Y. Yamamoto, B.A. Pint, K.A. Terrani, K.G. Field, Y. Yang, L.L. Snead, Development and property evaluation of nuclear grade wrought $\mathrm{FeCrAl}$ fuel cladding for light water reactors. J. Nucl. Mater. 467, 703-716 (2015)

18. Y. Alipour, P. Henderson, Corrosion-erosion of furnace wall materials in waste-wood fired power plant. Corrosion-erosion Eng., Sci. Technol. 50(5), 355-363 (2015)

19. Y. Alipour, A. Talus, P. Henderson, R. Norling, The effect of cofiring sewage sludge with used wood on the corrosion-erosion of a $\mathrm{FeCrAl}$ alloy and a nickel-based alloy in the furnace region. Fuel Process. Technol. 138, 805-813 (2015)

20. Y. Alipour High-temperature corrosion-erosion in a biomass-fired power boiler. Licentiate thesis, KTH Royal Institute of Technology, 2013.

21. C.O. Pettersson, T. Boellinghaus, T. Kannengiesser, Corrosionerosion testing of welds a review of methods. Weld World. 51, 79-106 (2007)

22. H. Kumar, S.K. Mohapatra, R.I. Singh, Review on CFD modelling of fluidized bed combustion systems based on biomass and co-firing. J. Inst. Eng. India Series C. 99(4), 449-474 (2018)

23. T.F. Dixon, A.P. Mann, F. Plaza, W.N. Gilfillan, Development of advanced technology for biomass combustion-CFD as an essential tool. Fuel. 84(10), 1303-1311 (2005). https://doi.org/10. 1016/j.fuel.2004.09.024

24. H.H. Mao, X. Qi, J. Cao, L.C. An, Y.T. Yang, Effect of Si on high-temperature oxidation of $30 \mathrm{Cr} 13$ stainless steel. J. Iron Steel Res. Int. 24, 561-568 (2017)

25. T.D. Nguyen, J. Zhang, D.J. Young, Effects of Silicon and water vapour on corrosion of $\mathrm{Fe}-20 \mathrm{Cr}$ and $\mathrm{Fe}-20 \mathrm{Cr}-20 \mathrm{Ni}$ alloys in $\mathrm{CO} 2$ at $650^{\circ} \mathrm{C}$. Oxid. Met. 87, 541-573 (2005)

26. Y.S. Li, Y. Niu, M. Spiegel, High-temperature interaction of Al/ Si-modified $\mathrm{Fe}-\mathrm{Cr}$ alloys with $\mathrm{KCl}$. Corros. Sci. 49, 1799-1815 (2007)

27. Y.S. Li, M. Spiegel, S. Shimada, Effect of $\mathrm{Al} / \mathrm{Si}$ addition on $\mathrm{KCl}$ induced corrosion of $9 \% \mathrm{Cr}$ steel. Mater. Lett. 58, 3787-3791 (2004)

28. Rikard Norling, Anders Hjörnhede, Mattias Mattsson, Long term testing of materials for tube shielding, stage 2. VÄRMEFORSK Service AB, 2012, ISSN 1653-1248

Publisher's Note Springer Nature remains neutral with regard to jurisdictional claims in published maps and institutional affiliations. 